\title{
PERILAKU MASYARAKAT DI BAGIAN TENGAH BATANG INO TERHADAP SAMPAH DI NAGARI SALIMPAUNG KECAMATAN SALIMPAUNG KABUPATEN TANAH DATAR
}

\author{
Achmad Norival \\ Program Studi Pendidikan Geografi \\ Jurusan Geografi \\ Fakultas Ilmu Sosial \\ Universitas Negeri Padang \\ email: ahmadnorival@gmail.com
}

\begin{abstract}
ABSTRAK
Penelitian ini bertujuan untuk mengetahui (1) perilaku masyarakat di bagian tengah Batang Ino terhadap sampah dan (2) faktor-faktor yang mempengaruhi perilaku masyarakat membuang sampah ke Batang Ino di Nagari Salimpaung Kecamatan Salimpaung Kabupaten Tanah Datar . Jenis penelitian ini adalah penelitian kualitatif. Data yang digunakan untuk melengkapi penelitian ini adalah data primer. Teknik pengumpulan data dalam penelitian ini menggunakan teknik observasi, wawancara, dan dokumentasi. Teknik analisis data yaitu dengan cara reduksi data, penyajian data, dan penarikan kesimpulan. Penelitian ini menghasilkan bahwa: (1) Perilaku masyarakat di bagian tengah Batang Ino terhadap sampah di Nagari Salimpaung Kabupaten Tanah Datar sebagian besar masih kurang baik hal ini dibuktikan dari sikap masyarakat pada umumnya membuang sampah ke Batang Ino, namun ada juga sebagian kecil dari mereka memilih untuk membakar sampah di belakang rumah. Sampah di Batang Ino juga berasal dari warga luar Nagari Salimpaung yang dibuang pada malam hari dekat jembatan Batang Ino. (2) ada dua faktor yang mempengaruhi perilaku masyarakat membuang sampah ke Batang Ino yang pertama faktor internal yaitu kurangnya pengetahuan tentang pengelolaan sampah, motivasi masyarakat, persepsi masyarakat tentang fungsi sungai dan faktor eksternal yaitu aspek fisik berupa fasilitas kebersihan yang belum tersedia di Nagari Salimpaung.
\end{abstract}

Kata Kunci :Perilaku Masyarakat, Sampah.

ABSTRACT

This study aims to determine (1) the behavior of society in the middle of Batang Ino toward garbage and (2) the factors that influence the behavior of society in throwing garbage to Batang Ino Salimpaung Tanah Datar regency. This was a qualitative research. The data used to complete the research was primary data. The techniques of data collection used in this research were observation, interview, and documentation. The data analysis used was measured by using data reduction, data presentation, and conclusion. This research resulted: (1) The behavior of society in middle of Batang Ino in toward garbage in Salimpaung Tanah Datar Regency mostly not really good. It couldbe seen from the society's behaviour. Most of the inhabitants threw the garbage to Batang Ino. However, some inhabitants tended to burn the garbage behind their house. The garbage also came from the inhabitants outside of Salimpaung, who disposed it near the bridge of Batang Ino at night. (2) there were two factors that influence the behavior of society in throwing garbage to Batang Ino. first the internal factor. That were lack of knowledge about waste management, the motivation, the perception about the function of the river. Second, the external factor, that was the facility higiene which is not availabel in Salimpaung.

Keywords: Behavior of society, Garbage.

${ }^{1}$ Mahasiswa Program Studi Pendidikan Geografi Untuk wisuda periode Maret 2018 
PENDAHULUAN

Masalah lingkungan hidup telah menjadi masalah pelik dalam keberlanjutan kehidupan di permukaan bumi karena pencemaran lingkungan yang di akibatkan oleh perilaku masyarakat yang kurang peduli terhadap lingkungan. Seperti pada saat ini yang banyak terjadi di perkotaan, lingkungan yang tercemari akibat limbah pabrik yang mengandung bahan kimia beracun sehingga membuat lingkungan terganggu pada beberapa daerah tertentu bahkan telah mencapai tingkat membahayakan kelangsungan makhluk hidup.

Pencemaran lingkungan adalah suatu perubahan lingkungan yang tidak menguntungkan, baik secara menyeluruh atau akibat hasil sampingan (langsung atau tidak langsung) dalam perubahanperubahan pola penggunaan energi dan materi. Tingkatan jumlah radiasi, bahanbahan fisika dan kimia, serta jumlah organisme (Pandia, 1996:6).

Kerugian yang ditimbulkan akibat oleh perilaku membuang sampah ke sungai jika ditinjau dari segi keseimbangan lingkungan, kesehatan, keamanan, dan pencemaran menurut Hadiwiyoto (1983) antara lain : 1) Sampah dapat menyebabkan pencemaran udara karena mengandung gas-gas yang terjadi dan rombakan sampah bau yang tidak sedap, daerah becek dan kadangkadang berlumpur terutama ketika musim penghujan datang; 2) Sampah yang bertumpuk dapat menimbulkan kondisi dari segi fisik dan kimia yang tidak sesuai dengan lingkungan normal, yang dapat mengganggu kehidupan disekitarnya; 3) Di sekitar pembuangan sampah akan terjadi kekurangan oksigen. Keadaan ini disebabkan karena proses perombakan sampah menjadi senyawa-senyawa sederhana di perlukan oksigen yang diambil dari udara disekitarnya. Karena kekurangan oksigen dapat menyebabkan kehidupan flora dan fauna menjadi terdesak; 4) Gas-gas yang di hasilkan selama degradasi (pembusukan) sampah dapat membahayakan karena kadangkadang proses pembusukan ada mengeluarakan gas beracun; 5) Dapat menimbulkan berbagai penyakit, terutama yang dapat ditularkan oleh lalat atau serangga lainnya, binatang seperti tikus, anjing dan; 6) Secara estetika sampah tidak dapat di golongkan sebagai pemandangan yang nyaman untuk di nikmati.

Salah satu bentuk pencemaran lingkungan yang terjadi pada saat ini terdapat di Batang Ino di Nagari Salimpaung Kabupaten Tanah Datar, tumpukan sampah yang ada di Batang Ino membuat kondisi sungai dipenuhi oleh sampah sehingga menimbulkan aroma yang tidak sedap serta mencemari air sungai, sampah-sampah tersebut seperti sampah pertanian, sampah rumah tangga, botol atau kaleng minuman, plastik makanan. Air sungai tersebut dimanfaatkan untuk pengairan irigasi, serta untuk mandi dan mencuci bagi masyarakat terlebih lagi sungai tersebut juga terletak di pinggir jalan raya Batusangkar-Bukittinggi sehingga 
menimbulkan pemandangan yang tidak enak dilihat.

Jika hal ini dibiarkan berlarut-larut maka akan semakin mencemari Batang Ino yang semakin hari di penuhi oleh sampah. Air yang telah tercemari oleh sampah tentu tidak baik bagi tanaman apalagi untuk mandi dan mencuci. Diperlukan usaha dan tindakan untuk menjaga serta menyelamatkan lingkungan hidup dari proses pencemaran lebih lanjut agar tidak munculnya bencana lingkungan disebabkan oleh masyarakat yang tidak bertanggung jawab terhadap keseimbangan hubungan antara manusia dengan lingkungan sehingga lingkungan menjadi rusak salah satunya ditentukan oleh perilaku masyarakat agar tidak lagi membuang sampah ke sungai.

Di perlukan adanya pengelolaan sampah yang baik mulai dari pengumpulan dan pengangkutan sampah ke tempat penampungan sementara (TPS) sampah, dan selanjutnya ke tempat penampungan akhir (TPA), kemudian pemusnahan dan pengelolaan sampah seperti ditanam (landfill), dibakar (incerenation), dan dijadikan pupuk (composting) dengan demikian permasalahan mengenai sampah akan berkurang.

Menurut Notoatmodjo (136:2011) Perilaku dan gejala perilaku yang tampak pada kegiatan organisme tersebut dipengaruhi baik oleh faktor genetik (keturunan) dan lingkungan. Secara umum dapat dikatakan bahwa faktor genetik dan lingkungan itu merupakan penentu dari perilaku makhluk hidup termasuk perilaku manusia. Hereditas atau faktor keturunan adalah konsepsi dasar atau modal untuk perkembangan perilaku makhluk hidup itu untuk selanjutnya. Sedangkan lingkungan adalah kondisi atau lahan untuk perkembangan perilaku tersebut. Suatu mekanisme pertemuan antara kedua faktor dalam rangka terbentuknya perilaku disebut proses belajar (learning proses).

Sarwono (2011:9) Perilaku atau tingkah laku adalah perbuatan manusia baik terbuka (Over Behavior) maupun tidak terbuka (Covert Behavior).Perilaku atau tingkah laku merupakan yang dapat ditangkap secara langsung melalui indera misalnya membuang sampah serta mengambil sampah yang berserakan dan yang tidak dapat ditangkap secara langsung oleh indera misalnya Motivasi, Sikap, Minat, dan Perasaan. Menurut Skinner dalam Achmadi (2013: 122) perilaku yang berhubungan dengan lingkungan banyak hal yang dapat dilakukan disini, mulai dari perilaku membuang sampah, perilaku bersin, berkendara agar tidak menyebabkan pencemaran udara, `membuang limbah rumah tangga, dan lain sebagainya.

Faktor-faktor yang mempengaruhi terbentuknya perilaku dapat dikelompokkan menjadi dua jenis, yaitu:

1. Faktor intern, yang mencakup: pengetahuan, kecerdasan, persepsi, emosi, motivasi, dan sebagainya yang berfungsi mengolah rangsangan dari luar. Motivasi merupakan penggerak 
perilaku, hubungan antara kedua kontruksi ini cukup kompleks, antara lain: (a) motivasi yang sama dapat diarahkan oleh motivasi yang berbeda demikian pula perilaku yang sama dapat saja diarahkan oleh motivasi yang berbeda, (b) motivasi menggerakkan perilaku pada tujuan tertentu, (c) penguatan positif menyebabkan satu perilaku tertentu cenderung untuk diulang kembali, (d) kekuatan perilaku dapat melemah akibat perbuatan itu bersifat tidak menyenangkan. Pengetahuan adalah hasil dari tahu, dan terjadi setelah seseorang melakukan melakukan pengindraan terhadap objek tertentu. Tanpa pengetahuan seseorang tidak mempunyai dasar untuk mengambil keputusan dan menentukan tindakan terhadap masalah yang dihadapi.

2. Faktor ekstern, meliputi lingkungan sekitar, baik fisik maupun nonfisik seperti: iklim, manusia, sosialekonomi, kebudayaan, dan sebagainya (Notoadmojo, 142: 2011).

Sampah adalah segala sesuatu yang tidak lagi dikehendaki oleh yang punya dan bersifat padat (Juli Soemirat,200:152). Sedangkan menurut (Azrul Azwar, 1996: 54) sampah adalah sebagian dari sesuatu yang tidak dipakai, tidak disenangi atau sesuatu yang harus dibuang, yang umumnya berasal dari kegiatan yang dilakukan oleh manusia (termasuk kegitan industry). Sedangkan menurut (Wibisono, 2014) sampah pada dasarnya merupakan suatu bahan yang terbuang dari suatu sumber hasil aktivitas manusia maupun proses-proses alam yang tidak memiliki nilai ekonomi, bahkan dapat mempunyai nilai ekonomi yang negatif karena penanganannya baik untuk membuang atau membersihkannya membutuhkann biaya yang cukup besar.

Menurut (Notoadmojo, 2011:190) Sampah adalah sesuatu bahan atau benda padat yang sudah tidak dipakai lagi oleh manusia, atau benda padat yang sudah tidak digunakan lagi dalam suatu kegiatan manusia dan dibuang. Para ahli kesehatan masyarakat Amerika membuat batasan, sampah (waste) adalah sesuatu yang tidak digunakan, tidak dipakai, tidak di senangi, atau sesuatu yang dibuang yang berasal dari kegiatan manusia, dan tidak terjadi dengan sendirinya. Dari batasan ini jelas bahwa sampah adalah hasil suatu kegiatan manusia yang dibuang karena sudah tidak berguna. Sehingga bukan semua benda padat yang tidak digunakan dan dibuang disebut sampah, misalnya: benda-benda alam, benda-benda yang keluar dari bumi akibat gunung meletus, banjir, pohon di hutan yang tumbang akibat angin rebut, dan sebagainya.

Menurut (Agus Maryono, 30: 2008) fungsi sungai yaitu:

a. fungsi sebagai saluran Eko-Drainase (Drainase Ramah Lingkungan), sungai dalam suatu sistem sungai (river basin) merupakan komponen eko-drainase utama pada basin yang bersangkutan. Bentuk dan ukuran alur sungai alamiah, dalam kaitannya dengan ekodrainase, merupakan bentuk yang sesuai dengan kondisi geologi, geografi, ekologi, dan hidrologi daerah 
tersebut. Konsep alamiah eko-drainase adalah bagaimana membuang air kelebihan selambat-lambatnya ke sungai.

b. fungsi sebagai saluran irigasi. Dalam perencanaan bangunan irigasi teknis sungai yang dapat dipakai sebagai saluran irigasi teknis, jika dari segi teknis memungkinkan. Kehilangan air di saluran dengan menggunakan sungai kecil lebih kecil dari pada menggunakan saluran tanah buatan, karena pada umumnya porositas sungai relatif rendah mengingat adanya kandungan lumpur dan sedimen gradasi kecil yang relatif tinggi.

c. fungsi ekologi, sungai mempunyai fungsi vital kaitannya dengan ekologi. Sungai dan bantarannya merupakan habitat yang sangat kaya akan flora dan fauna sekaligus sebagai barometer kondisi ekologi daerah tersebut.

Menarik untuk dijadikan sebuah kajian ilmiah, berdasarkan uraian di atas maka penulis tertarik untuk meneliti dan mengambil judul penelitian tentang "Perilaku Masyarakat di Bagian Tengah Batang Ino Terhadap Sampah di Nagari Salimpaung Kecamatan Salimpaung Kabupaten Tanah Datar".

\section{METODE PENELITIAN}

Berdasarkan langkah-langkah yang dilakukan maka penelitian ini digolongkan dalam penelitian "Deskriptif Kualitatif” yaitu berusaha mengungkapkan perilaku masyarakat di Bagian Tengah Batang Ino terhadap sampah di Nagari Salimpaung Kabupaten Tanah Datar. Menurut Arikunto (2006) Penelitian Kualitatif dilakukan dan terjadi secara ilmiah, apa adanya, dalam situasi normal tidak dimanipulasi keadaan dan kondisinya.

Sebagaimana di tuangkan dalam judul penelitian ini, maka yang dijadikan daerah penelitian ini adalah Nagari Salimpaung Kabupaten Tanah Datar, untuk mengetahui mengenai Perilaku Masyarakat di Bagian Tengah Batang Ino Terhadap Sampah diNagari Salimpaung Kabupaten Tanah Datar.Penelitian ini dilaksanakan pada semester ganjil tahun ajaran 2017/2018. Penelitian ini dimulai pada tanggal 13 Agustus 2017 sampai dengan tanggal 30 September 2017.

Teknik pemilihan informan adalah purposive sampling, menurut Sugiyono (2011:301) purposive sampling adalah teknik pengambilan sumber data dengan pertimbangan tertentu. Pertimbangan tertentu ini misalnya orang tersebut dianggap paling tau tentang apa yang kita harapkan, atau mungkin dia sebagai penguasa sehingga akan memudahkan peneliti menjelajahi objek atau situasi yang diteliti. Jumlah informan masyarakat adalah sebanyak 19 orang karena penambahan sampel dihentikan manakala datanya sudah jenuh dari berbagai informan baik yang lama maupun yang baru, tidak memberikan data baru lagi dan Informan kunci dari subjek penelitian ini adalah Wali Nagari Salimpaung dan Dinas PERKIM LH Kabupaten Tanah Datar. 
Data primer, adalah data yang diperoleh langsung melalui Observasi atau pengamatan langsung, wawancara, perekaman, atau pemotretan dengan informan yang telah ditetapkan atau melalui orang lain yang telah ditetapkan sebagai objek penelitian untuk memperoleh penyelesaian fakta di lapangan. Data primer di kumpulkan melalui wawancara semiterstruktur secara langsung dan dengan kamera. Data primer dalam penelitian ini adalah masyarakat Nagari Salimpaung. Data Skunder, data ini diperoleh melalui studi pustaka yaitu dari buku-buku, koran, majalah, data statistik, jurnal, internet dan lain-lain yang terkait dengan penelitian dan data skunder juga dihimpun dari kantor BPS Kabupaten Tanah Datar yaitu data tentang jumlah sungai yang melalui Kecamatan Salimpaung, jumlah sarana pendidikan di Nagari Salimpaung, dan komposisi penduduk Nagari Salimpaung menurut jenis kelamin..

Pengambilan data yang relevan dilakukan dengan menggunakan teknik pengumpulan data informasi dengan cara observasi, wawancara, dan dokumentasi.

Di dalam sebuah penelitian, triangulasi diperlukan sebagai alat untuk menguji keabsahan data dan objektivitas cara yang diberikan oleh subjek penelitian Untuk memeriksa keabsahan data dalam penelitian ini, maka penulis menggunakan teknik triangulasi data yang merupakan teknik pemeriksaan data yang memanfaatkan sesuatu yang lain diluar data itu untuk keperluan pengecekan atau sebagai bahan pembanding data tersebut.
Menurut Sugiyono (2011) terdapat 3 bentuk triangulasi sumber, triangulasi teknik, triangulasi waktu.

Triangulasi yang digunakan oleh peneliti adalah pemeriksaan melalui sumber lainnya, yang dapat dicapai dengan jalan: membandingkan data hasil pengamatan dengan hasil wawancara; membandingkan data hasil wawancara dengan isi suatu dokumen yang terkait; membandingkan teori dengan pelaksanaan dalam prakteknya.

Metoda analisa data yang dipakai dalam penelitian ini melalui beberapa tahap analisa data Millies dan A Hubberman dalam Nufus (2010) adalah: Reduksi, klasifikasi data, dan pengambilan kesimpulan.

\section{HASIL PENELITIAN DAN PEMBAHASAN}

Hasil wawancara dan pengamatan yang peneliti lakukan di Nagari Salimpaung diperoleh informasi bahwa Perilaku Masyarakat di Bagian Tengah Batang Ino Terhadap Sampah di Nagari Salimpaung sebagian besar kurang baik hal ini dibuktikan dari sikap masyarakat yang tinggal dekat aliran Batang Ino pada umumnya membuang sampah ke Batang Ino, sampah dikumpulkan di dalam ember atau kantong plastik setelah itu dibuang ke Batang Ino, namun ada juga sebagian kecil dari mereka memilih untuk membakar sampah di belakang rumah. Sampah di Batang Ino juga berasal dari warga luar Nagari Salimpaung yang dibuang pada malam hari dekat jembatan Batang Ino. 
Berdasarkan wawancara peneliti dengan masyarakat, Wali Nagari, dan Dinas PERKIM LH tentang faktor-faktor yang mempengaruhi perilaku masyarakat membuang sampah ke Batang Ino di Nagari Salimpaung, peneliti melihat masih kurangnya pengetahuan dan motivasi masyarakat terhadap sampah, masyarakat juga tidak mengetahui dampak yang ditimbulkan dari sampahsampah tersebut.

Pengetahuan masyarakat akan
bahaya yang ditimbulkan dari
pembuangan sampah di Batang Ino
kurang, hal ini dibuktikan dari kebiasaan
dan perilaku masyarakat. Persepsi
masyarakat tentang fungsi sungai yang
beranggapan bahwa sungai merupakan
tempat untuk membuang sampah.

Sedangkan dalam motivasi masyarakat untuk tidak membuang sampah di sekitar Batang Ino masih kurang, hal ini di buktikan tidak adanya fasilitas kebersihan yang disediakan oleh Dinas PERKIM LH serta tidak menghiraukan himbauan yang disampaikan oleh wali nagari di tempat umum seperi masjid setiap hari jumat dan juga penyuluhan dari Dinas PERKIM LH untuk gerakan Tanah Datar bersih. Selain itu juga telah dipasang banner maupun spanduk larangan membuang sampah namun tidak ada yang menghiraukan. Untuk memperoleh kebenaran informasi, peneliti melakukan wawancara dengan Wali Nagari Salimpaung dan Dinas PERKIM LH, diperoleh informasi bahwa untuk tempat sampah sementara di Nagari Salimpaung memang belum ada hal ini dikarenakan masalah biaya operasional yang masih terbatas, himbauan sudah sering di dilakukan tapi hanya sedikit masyarakat yang mengindahkan. 


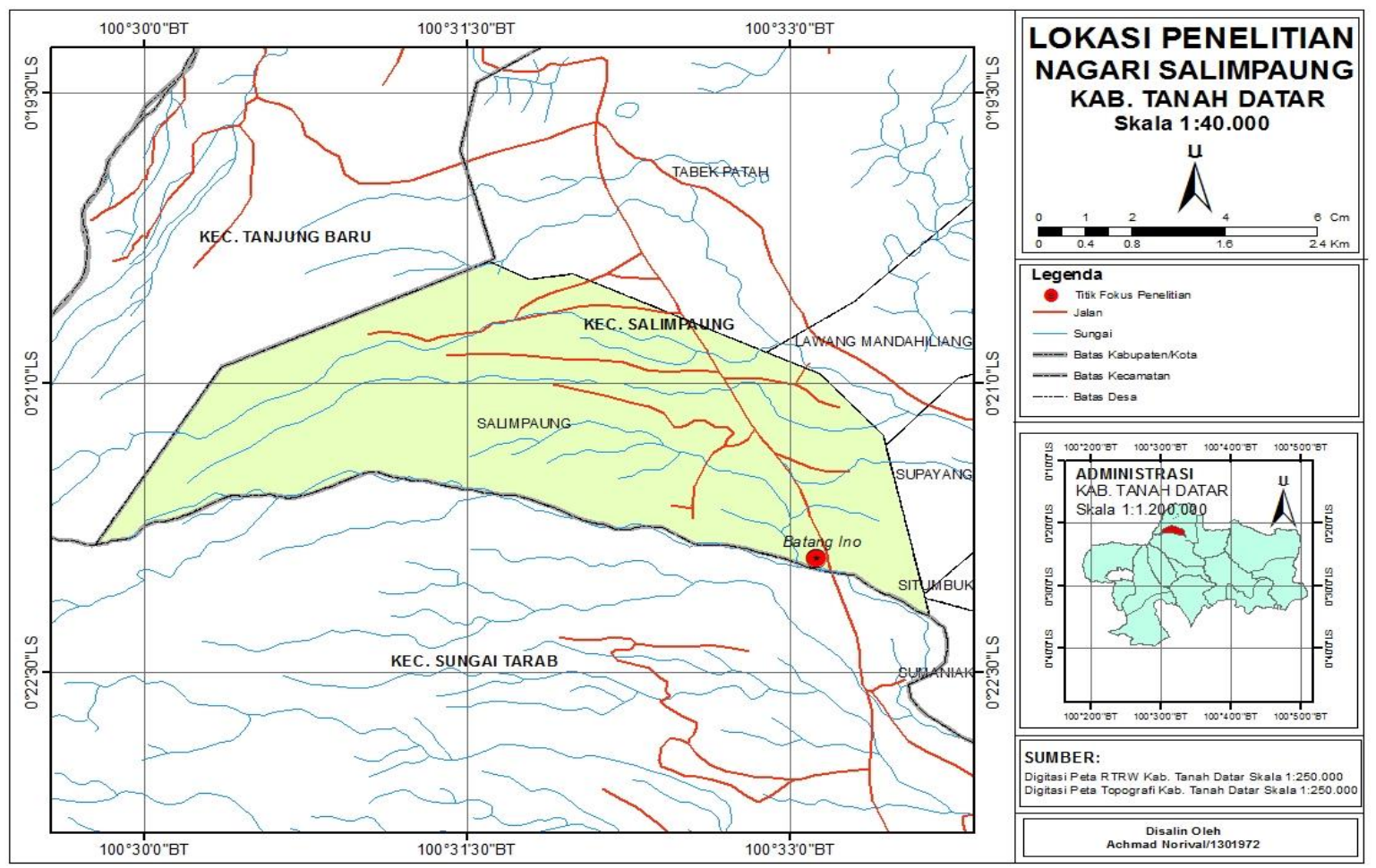

Gambar 1. Peta Lokasi Penelitian

\section{PEMBAHASAN}

Berdasarkan hasil penelitian yang telah ditemui peneliti saat di lapangan melalui Observasi, Wawancara, dan Dokumentasi maka diperoleh hasil penelitian sebagai berikut:

Pertama, Perilaku Masyarakat di Bagian Tengah Batang Ino Terhadap Sampah di Nagari Salimpaung sebagian besar kurang baik hal ini dibuktikan dari sikap masyarakat yang tinggal dekat aliran Batang Ino pada umumnya membuang sampah ke Batang Ino, sampah dikumpulkan di dalam ember atau kantong plastik setelah itu dibuang ke Batang Ino, namun ada juga sebagian kecil dari mereka memilih untuk membakar sampah di belakang rumah. Sampah di Batang Ino juga berasal dari warga luar Nagari Salimpaung yang dibuang pada malam hari dekat jembatan Batang Ino. Peneliti menilai perilaku masyarakat di bagian tengah Batang Ino terhadap sampah berdasarkan indikator dan fakta yang diihat langsung oleh peneliti. Adapun indikator yang menjadi penilaian peneliti untuk mengetahui perilaku masyarakat menurut menurut Azwar (2005:87-104), yaitu: 1) Observasi perilaku, 2) Pertanyaan langsung, 3) Pengungkapkan langsung, 4) Skala Sikap, 5) Pengukuran terselubung. Untuk indikator pertanyaan langsung, peneliti mengetahui perilaku masyarakat dengan memberikan pertanyaan kepada informan, seperti bagaimana bapak/ibu dalam mngelola sampah di rumah, mereka menjawab sampah dikumpulkan dalam 
ember atau plastik setelah itu dibakar atau dibuang ke Batang Ino. Tidak ada tempat sampah khusus yang disediakan di rumah.

Sedangkan menurut Sarwono (2011:9) Perilaku atau tingkah laku adalah perbuatan manusia baik terbuka (Over Behavior) maupun tidak terbuka (Covert Behavior). Perilaku atau tingkah laku merupakan tingkah laku yang dapat ditangkap secara langsung melalui indera misalnya membuang sampah serta mengambil sampah yang berserakan dan yang tidak dapat ditangkap secara langsung oleh indera misalnya Motivasi, Sikap, Minat, dan Perasaan. Menurut Menurut (Kusrini, 2015) perilaku membuang sampah tidak pada tempatnya tentunya akan berdampak pada manusia itu sendiri. Apabila manusia menyadari tindakan tersebut bahkan menjadi kebiasaan yang tidak terpikirkan dampaknya, maka akan bertambah kerusakan di bumi ini.

Berdasarkan pengamatan yang dilakukan peneliti terhadap perilaku masyarakat melalui wawancara dan pengamatan maka peneliti mengetahui :

Kedua Faktor-faktor yang mempengaruhi perilaku masyarakat membuang sampah ke Batang Ino adalah faktor internal seperti, pengetahuan, motivasi, dan persepsi masyarakat, kurangnya pengetahuan masyarakat tentang pengelolaan sampah, dampak yang akan ditimbulkan dari sampahsampah tersebut, motivasi untuk merubah perilaku membuang sampah ke sungai bagi masyarakat sudah ada pemberitahuan dari pemerintah Nagari tetapi masih saja membuang sampah ke Batang Ino karena tanpa pengetahuan seseorang tidak memiliki dasar untuk mengambil suatu keputusan dan mengambil tindakan terhadap masalah yang dihadapi. Motivasi merupakan penggerak dari perilaku pada tujuan tertentu. Persepsi masyarakat tentang fungsi sungai yang menganggap sungai merupakan tempat untuk membuang sampah dan faktor eksternal berupa fasilitas tempat sampah sampah yang belum tersedia di Nagari Salimpaung. Menurut (Rizal, 2011) ketersediaan sarana prasarana dalam pengelolaan kebersihan dan persampahan merupakan suatu hal yang mutlak untuk dimiliki. Mengingat pengelolaan kebersihan dan persampahan suatu proses manajemen yang harus direncanakan, dilaksanakan dan dikontrol dengan baik.

Seperti yang dikatakan Notoatmodjo (2011:142) faktor-faktor yang mempengaruhi terbentuknya perilaku dapat dikelompokkan menjadi dua jenis, yaitu: a). Faktor intern, yang mencakup: pengetahuan, kecerdasan, persepsi, emosi, motivasi, dan sebagainya yang berfungsi mengolah rangsangan dari luar. Motivasi merupakan penggerak perilaku, hubungan antara kedua kontruksi ini cukup kompleks, antara lain: (a) motivasi yang sama dapat diarahkan oleh motivasi yang berbeda demikian pula perilaku yang sama dapat saja diarahkan oleh motivasi yang berbeda, (b) motivasi menggerakkan perilaku pada tujuan tertentu, (c) penguatan positif menyebabkan satu perilaku tertentu 
cenderung untuk diulang kembali, (d) kekuatan perilaku dapat melemah akibat perbuatan itu bersifat tidak menyenangkan. Pengetahuan adalah hasil dari tahu, dan terjadi setelah seseorang melakukan melakukan pengindraan terhadap objek tertentu. Tanpa pengetahuan seseorang tidak mempunyai dasar untuk mengambil keputusan dan menentukan tindakan terhadap masalah yang dihadapi. 2). Faktor ekstern, meliputi lingkungan sekitar, baik fisik maupun nonfisik seperti: iklim, manusia, sosial-ekonomi, kebudayaan, dan sebagainya.

Saat diwawancarai, masyarakat mengatakan sampah dibuang ke Batang Ino sekali seminggu dan ada juga sekali tiga hari, sampah-sampah tersebut akan hanyut jika dibuang ke sungai, masyarakat juga mengatakan sampahsampah yang ada di Batang Ino juga dibuang oleh orang yang sekedar lewat kira-kira jam 4 pagi atau tengah malam tidak ada fasilitas kebersihan disediakan yang ada hanya berupa larangan himbauan dari pemerintah Nagari. Untuk mencari kebenaran informasi, peneliti melakukan wawancara dengan Wali Nagari dan Dinas PERKIM LH kemudian didapat informasi bahwa memang belum ada fasilitas kebersihan yang disediakan di Nagari Salimpaung karea masalah biaya operasional, namun himbauan terkait larangan membuang sampah ke Batang Ino sudah sering dilakukan dimasjid dan tempat-tempat umum serta penyuluhan dari Dinas PERKIM LH dan di Batang Ino juga telah di pasang spanduk dan Banner terkait larangan membuang sampah namun tidak juga di patuhi oleh masyarakat.

\section{PENUTUP}

\section{Kesimpulan}

Perilaku masyarakat di bagian tengah Batang Ino terhadap sampah di Nagari Salimpaung Kabupaten Tanah Datar sebagian besar masih kurang baik hal ini dibuktikan dari sikap masyarakat yang tinggal dekat aliran Batang Ino pada umumnya membuang sampah ke Batang Ino, sampah dikumpulkan di dalam ember atau kantong plastik setelah itu dibuang ke Batang Ino, namun ada juga sebagian kecil dari mereka memilih untuk membakar sampah di belakang rumah. Sampah di Batang Ino juga berasal dari warga luar Nagari Salimpaung yang dibuang pada malam hari dekat jembatan Batang Ino.

Faktor-faktor yang mempengaruhi perilaku masyarakat membuang sampah ke Batang Ino adalah faktor internal, kurangnya pengetahuan tentang pengelolaan sampah, motivasi masyarakat untuk merubah perilaku membuang sampah ke Batang Ino, dan persepsi masyarakat tentang fungsi sungai yang menganggap sungai sebagai tempat untuk membuang sampah dan faktor eksternal yaitu aspek fisik berupa fasilitas kebersihan yang belum tersedia di Nagari Salimpaung.

\section{Saran}

Berdasarkan kesimpulan di atas, maka peneliti mengajukan saran beberapa 
hal sebagai berikut: 1) Masyarakat diharapkan untuk tidak lagi membuang sampah ke Batang Ino terutama masyarakat Nagari Salimpaung. 2) Diharapkan adanya kontrol masyarakat Nagari Salimpaung khususnya masyarakat yang tinggal dekat jembatan Batang Ino untuk melarang warga yang

\section{DAFTAR PUSTAKA}

Achmadi umar, F. 2013. Kesehatan Masyarakat Teori Dan Aplikasi. Jakarta: Rajawali Pers.

Arikunto, Suharsimi. 2006. Prosedur Penelitian Suatu Pendekatan Praktik. Jakarta: Rineka Cipta.

Azrul, Azwar. 1996. Pengantar Ilmu Kesehatan Lingkungan. Jakarta: Mutiara Sumber Widya.

Azwar, Saifuddin. 2005. Perilaku Manusia Teori dan Pengukurannya. Yogyakarta: Pustaka Belajar.

Hadiwijoto, S. 1983. Penanganan dan Pemanfaatan Sampah. Jakarta: Yayasan Iadayu.

Juli, Soemirat. 2002. Kesehatan

Lingkungan. Yogyakarta: Universitas Gajah Mada.

Kusrini, Tri. 2015. Perilaku Membuang Sampah oleh Masyarakat di Tepian Sungai Kapuas. Skripsi. Fakultas Ilmu Sosial dan Politik Universitas Tanjungpura membuang sampah di dekat jembatan Batang Ino. 3) Diharapkan kedepannya ada Perda Kabupaten dan peraturan dari Nagari yang mengatur tentang kebersihan dan keindahan di Kabupaten Tanah Datar. 4) Diharapkan kepada Dini JERKIM LH, untuk menyediakan fasilitas kebersihan di Nagari Salimpaung.

Pontianak Volume 3 No. 3 Tahun 2015.

Maryono, Agus. 2008. Eko-Hidraulik Pengelolaan Sungai Ramah Lingkungan. Yogyakarta: Gadjah Mada University Press.

Notoatmodjo, Soekidjo. 2011. Kesehatan Masyarakat Ilmu \& Seni. Jakarta: PT Rineka Cipta.

Nufus, Hayatun. 2010. Fungsi Batang Selo Bagi Masyarakat Kenagarian Pagaruyung Kecamatan Tanjung Emas. Skripsi FIS UNP, Padang.

Pandia, Setiaty dkk. 1996. Kimia Lingkungan. Medan: USU.

Rizal, Muhammad. 2011. Analisis Pengelolaan Persampahan Perkotaan. Jurnal Smartek Volume 9 No. 2 Tahun 2011.

Sarwono. 2011. Pengantar Umum Psikologi. Bulan Bintang, Jakarta. 
Sugiyono. 2011. Metode Penelitian

Kombinasi (mixed methods).

Bandung: Alfabeta.
Jagonayan Kecamatan Ngablak. Jurnal Inovasi dan Kewirausahaan Volume 3 No.1 Tahun 2014.

Wibisono, Dewi. 2014. Sosialisasi

Bahaya Membuang Sampah Sembarangan dan Menentukan

Lokasi TPA di dusun Deles Desa 